\title{
Regulated and Non-Regulated Emissions from Euro 6 Diesel, Gasoline and CNG Vehicles under Real-World Driving Conditions
}

\author{
Ricardo Suarez-Bertoa ${ }^{1, * \mathbb{C}}$, Martin Pechout ${ }^{2}$, Michal Vojtíšek ${ }^{3,4}{ }^{(0)}$ and Covadonga Astorga ${ }^{1}$ \\ 1 European Commission Joint Research Centre, 21027 Ispra, Italy; \\ Covadonga.ASTORGA-LLORENS@ec.europa.eu \\ 2 Department of Vehicles and Ground Transport, Faculty of Engineering, Czech University of Life Sciences, \\ Kamycka 127, 16521 Praha, Czech Republic; pechout@tf.czu.cz \\ 3 Department of Vehicles and Engines, Technical University of Liberec, 46117 Liberec, Czech Republic; \\ michal.vojtisek@tul.cz \\ 4 Department of Automotive, Combustion Engine and Railway Engineering, Faculty of Mechanical \\ Engineering, Czech Technical University of Prague, Technicka 4, 16000 Prague, Czech Republic; \\ michal.vojtisek@fs.cvut.cz \\ * Correspondence: Ricardo.suarez-bertoa@ec.europa.eu; Tel.: +39-0332-78-3756
}

Received: 19 January 2020; Accepted: 11 February 2020; Published: 14 February 2020

check for updates

\begin{abstract}
The transport sector is one of the main sources air pollutants. Different exhaust after-treatment systems have been implemented over the years to control the emissions of criteria pollutants. However, while reducing the emissions of the target compounds these systems can lead to the emissions of other pollutants and/or greenhouse gases such as $\mathrm{NH}_{3}$ or $\mathrm{N}_{2} \mathrm{O}$. Following the implementation of the Real Driving Emissions (RDE) test procedure in the EU, vehicles have been equipped with more complex after-treatment configurations. The impact that these technologies may have on the emissions of non-regulated pollutants during real-world driving have not been evaluated until now. In the current study we present the on-road emissions of a series of non-regulated pollutants, including $\mathrm{NH}_{3}, \mathrm{~N}_{2} \mathrm{O}, \mathrm{CH}_{4}$ and $\mathrm{HCHO}$, measured with a portable FTIR from a series of Euro 6d, Euro 6c and Euro 6d-TEMP, gasoline diesel and compressed natural gas (CNG) vehicles during real-world testing. The obtained results show that it is possible to measure $\mathrm{N}_{2} \mathrm{O}, \mathrm{NH}_{3}, \mathrm{CH}_{4}$ and $\mathrm{HCHO}$ during on-road operation. The results also highlight the importance of the measurement of the emissions of these pollutants during real-world driving, as the emissions of $\mathrm{NH}_{3}$ (a particulate matter precursor) and those of $\mathrm{N}_{2} \mathrm{O}$ and $\mathrm{CH}_{4}$ (green-house gases) can be high from some vehicle technologies. $\mathrm{NH}_{3}$ emissions were up to $49 \mathrm{mg} / \mathrm{km}$ for gasoline passenger cars, up to $69 \mathrm{mg} / \mathrm{km}$ for the CNG light-commercial vehicle and up to $17 \mathrm{mg} / \mathrm{km}$ a diesel passenger car equipped with a selective catalytic reduction system (SCR). On the other hand, $\mathrm{N}_{2} \mathrm{O}$ and $\mathrm{CH}_{4}$ emissions accounted for up to $9.8 \mathrm{~g} \mathrm{CO}_{2}$ eqv $/ \mathrm{km}$ for a diesel passenger car equipped with a combination of diesel oxidation catalysts (DOC), lean $\mathrm{NO}_{\mathrm{x}}$ traps (LNT), SCR and possibly an ammonia slip catalyst ASC.
\end{abstract}

Keywords: Euro 7; vehicle emissions; $\mathrm{RDE}$; unregulated pollutants; ammonia; $\mathrm{N}_{2} \mathrm{O}$; $\mathrm{HCHO}$

\section{Introduction}

Road transport is one of the major sources of air pollutants and greenhouse gases in Europe [1]. The main primary air pollutants include: particulate matter $(\mathrm{PM}), \mathrm{NO}_{\mathrm{x}}$ (which includes both $\mathrm{NO}$ and $\mathrm{NO}_{2}$ ), $\mathrm{NH}_{3}, \mathrm{CO}$, volatile organic compounds (VOCs) including $\mathrm{CH}_{4}$. The key secondary air pollutants related to traffic emissions are $\mathrm{PM}$ (formed in the atmosphere), $\mathrm{O}_{3}, \mathrm{NO}_{2}$ and several oxidized VOCs [1]. The gases: $\mathrm{SO}_{2}, \mathrm{NO}_{\mathrm{x}}, \mathrm{NH}_{3}$ and VOCs are the main precursors of $\mathrm{PM}$ and $\mathrm{NO}_{\mathrm{x}}$, non-methane volatile 
organic compounds (NMVOCs) and $\mathrm{CH}_{4}$ are the main precursors of ground-level (tropospheric) $\mathrm{O}_{3}$. Aiming at improving Europe's air quality, policy actions have increasingly been taken to address transport-related air pollution. At European Union (EU) level, this has included the regulation of emissions by setting emission standards (Euro 1 to Euro 6) or by setting requirements for fuel quality.

To meet these standards, passenger cars have been equipped with different emission control systems. Thus, three-way catalytic converters (TWC) are commonly used to reduce the emissions of CO, hydrocarbons $(\mathrm{HC})$ and $\mathrm{NO}_{\mathrm{x}}$ from gasoline cars. In the case of diesel cars, $\mathrm{CO}$ and $\mathrm{HC}$ emissions are reduced using diesel oxidation catalysts $(\mathrm{DOC})$, and $\mathrm{NO}_{\mathrm{x}}$ emissions using selective catalytic reduction systems (SCR), lean $\mathrm{NO}_{x}$ traps (LNT) or a combination of both. While reducing the emissions of the target compounds these systems can lead to the emissions of other pollutants that are not currently regulated for the passenger cars in the EU. The emitted pollutants include $\mathrm{NH}_{3}[2,3]$ and $\mathrm{N}_{2} \mathrm{O}$. In fact, several laboratory-based studies have indicated that vehicle emissions of $\mathrm{NH}_{3}$ and $\mathrm{N}_{2} \mathrm{O}$ are linked to the use of TWC, DOC, SCR and/or LNT [4-8]. While $\mathrm{N}_{2} \mathrm{O}$ is a powerful greenhouse gas and the single most important ozone-depleting substance (ODS) [9], $\mathrm{NH}_{3}$ is a precursor of ammonium nitrate and sulfate $[10,11]$, which are the most abundant atmospheric secondary inorganic aerosols in many regions [2,12]. They degrade urban air quality [13], affect human health [14], and impact the global radiation budget $[15,16]$. Moreover, deposition of ammonium species may lead to eutrophication of waters and acidification of soils with negative effects on nitrogen-containing ecosystems [17-19]. Moreover, $\mathrm{NH}_{3}$ enhances particle nucleation by several orders of magnitude, increasing the number of potential cloud condensation nuclei which affects climate [20].

Recent studies have indicated that transport is the main source of $\mathrm{NH}_{3}$ in some urban areas worldwide [21-25]. $\mathrm{NH}_{3}$ emissions have been linked to rich combustion operation of gasoline and liquefied petroleum gas (LPG) vehicles equipped with TWC. Fuel-rich combustion has been used at high engine loads to increase the maximum engine power output, while avoiding excessive knock or excessive exhaust gas temperatures. This practice has been prohibited in the U.S. [26]. During this combustion operation $\mathrm{NO}_{x}$ and $\mathrm{H}_{2}$ react and form $\mathrm{NH}_{3}$ over the TWC increasing the emissions of $\mathrm{NH}_{3}$, which is not regulated for light-duty vehicles. As a result, $\mathrm{NH}_{3}$ is now the dominant reactive nitrogen species emitted by gasoline and LPG vehicles [27,28], including hybrids [29,30]. Moreover, the budget of transport-related $\mathrm{NH}_{3}$ emissions has been expected to increase as a result of a more intensive use of the SCR systems installed by the most recent diesel vehicles in order to meet the $\mathrm{NO}_{\mathrm{x}}$ requirements recently introduced with real driving emissions (RDE) procedure [31,32]. This, on the other hand, was predicted to further increase the total budget of vehicular emissions of $\mathrm{NH}_{3}$ and $\mathrm{N}_{2} \mathrm{O}$. $\mathrm{NH}_{3}$ and $\mathrm{N}_{2} \mathrm{O}$ emissions from passenger cars are not regulated in the EU. Therefore, the use of modern vehicles equipped with these after-treatments raises new environmental and health concerns, since unknown amounts of $\mathrm{NH}_{3}$ and $\mathrm{N}_{2} \mathrm{O}$ will be emitted.

Measurement during on-road operation under the RDE tests procedures using current portable emissions systems (PEMS) allows the analysis of emissions of $\mathrm{NO}_{x}, \mathrm{CO}, \mathrm{CO}_{2}, \mathrm{CH}_{4}$, and $\mathrm{HC}$ under different driving conditions with real on-road variables. However, current PEMS do not allow the measurement of $\mathrm{NH}_{3}, \mathrm{HCHO}$ and in most cases $\mathrm{N}_{2} \mathrm{O}$. For that reason, we explored the possibility of their measurement using laboratory grade instrumentation during on-road operation. In previous studies we showed that it is possible to measure $\mathrm{NH}_{3}$ and $\mathrm{N}_{2} \mathrm{O}$ emissions from heavy-duty and light-commercial vehicles during on-road operation using laboratory grade quantum cascade laser detectors (QCL-IR) and Fourier Transform InfraRed spectroscopy (FTIR) [33-35]. We also showed that during on-road operation a gasoline passenger car and a series of CNG light-commercial vehicles present substantial emissions of $\mathrm{NH}_{3}$ and diesel vehicles equipped with SCR presented low $\mathrm{NH}_{3}$ emissions [20,24]. The instruments used in these studies presented two important drawbacks: (i) the weight, as the QCL-IR and the FTIR used for the light-commercial vehicles were heavy lab-grade instruments ( 200 kg) and (ii) data acquisition frequency of the lighter FTIR (approximately $40 \mathrm{~kg}$ ) used to test the passenger cars was lower than $1 \mathrm{~Hz}(3 \mathrm{~s})$. Moreover, the FTIR used in Suarez-Bertoa et 
al. [31] was validated only for $\mathrm{NH}_{3}$ versus a lab-grade FTIR and $\mathrm{NO}_{\mathbf{x}}$ versus a PEMS, and the FTIR used in Vojtíšek-Lom et al. [35] was not validated for $\mathrm{NH}_{3}$ and $\mathrm{N}_{2} \mathrm{O}$.

In the current study, we aim to investigate the emissions of pollutants that are not regulated in Europe at the moment from a series of the most recent vehicles available in the EU market, including gasoline, diesel and compressed natural gas $(\mathrm{CNG})$ vehicles, using a portable FTIR. This instrument allows the measurement of those gaseous compounds measured by PEMS $\left(\mathrm{NO}_{\mathrm{x}}, \mathrm{CO}, \mathrm{CO}_{2}\right)$, and also, and more importantly for the scope of this study, $\mathrm{NH}_{3}, \mathrm{~N}_{2} \mathrm{O}, \mathrm{CH}_{4}$ and $\mathrm{HCHO}$. The objective is also to provide evidence of the extend of the $\mathrm{NH}_{3}$ and $\mathrm{N}_{2} \mathrm{O}$ emissions from diesel vehicles that were designed to meet $\mathrm{NO}_{\mathrm{x}}$ requirements during $\mathrm{RDE}$ testing.

We critically discuss on-road emissions of $\mathrm{N}_{2} \mathrm{O}$ and put them into perspective by calculating the $\mathrm{CO}_{2}$ equivalency of the mass emitted. Finally, we highlight the importance of gasoline and the latest diesel vehicles as source of $\mathrm{NH}_{3}$. The obtained results could be used to refine $\mathrm{NH}_{3}$ and $\mathrm{N}_{2} \mathrm{O}$ emission inventories and consequently could help on the quantification of the impact of $\mathrm{NH}_{3}$ urban sources in future air quality models and legislation, as well as to better quantify the contribution of the transport sector to the greenhouse gas (GHG) budget.

\section{Experiments}

Four passenger cars-two gasoline direct injection (GV1 and GV2), two diesels (DV1 and DV2) and one CNG light commercial (CNG-LCV) vehicles-were tested on-road during the summer season in northern Italy by the Joint Research Centre (JRC) (see altitude and speed profiles of the routes in the Figure S1 of the supplementary material). The routes used fulfill the requirements of the RDE test procedure (see Table 1 for vehicle specifications and Table 2 for routes description). During the testing campaign the ambient temperature was $25{ }^{\circ} \mathrm{C} \pm 2{ }^{\circ} \mathrm{C}$ and relative humidity $47 \% \pm 13 \%$. While the gasoline and CNG vehicles were pre-RDE (GV1, GV2 and CNG-LCV were Euro 6c, Euro $6 \mathrm{~b}$ and Euro 6b, respectively), the diesel vehicles were Euro 6d-TEMP, and hence type-approved with RDE. Exhaust emissions of $\mathrm{NO}_{\mathrm{x}}\left(\mathrm{NO}\right.$ and $\left.\mathrm{NO}_{2}\right), \mathrm{CO}, \mathrm{NH}_{3}, \mathrm{~N}_{2} \mathrm{O}, \mathrm{HCHO}$ and $\mathrm{CH}_{4}$ were comprehensively studied using a certified PEMS and a portable FTIR by combining on-road measurements during normal (RDE-compliant) and dynamic driving (see below).

Table 1. Vehicle specifications.

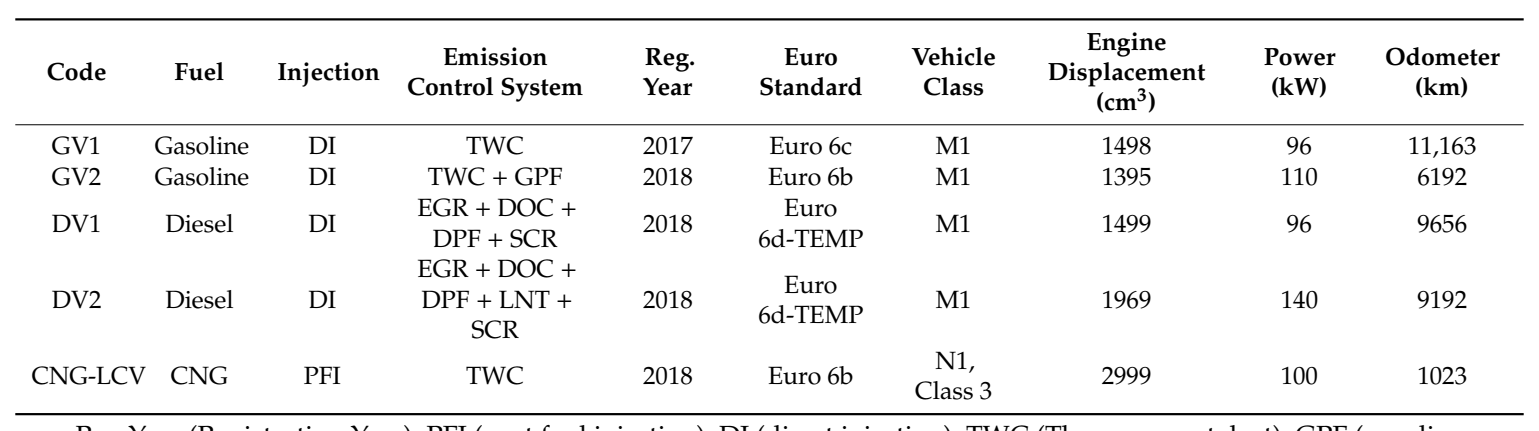

Reg.Year (Registration Year); PFI (port fuel injection); DI (direct injection); TWC (Three-way catalyst); GPF (gasoline particle filter); DOC (diesel oxidation catalyst); EGR (exhaust gas recirculation); DPF (diesel particle filter); LNT (lean NOx trap); SCR (selective catalyst reduction system); CNG (compressed natural gas).

The portable FTIR was a BRUKER MATRIX-MG5. The device consisted of a silicon carbide source (at $1200^{\circ} \mathrm{C}$ ), a $5 \mathrm{~m}$ multi-reflection gas cell, a RockSolid ${ }^{\mathrm{TM}}$ interferometer (spectral resolution: $0.5 \mathrm{~cm}^{-1}$, spectral range: $750-4800 \mathrm{~cm}^{-1}$ ) and a liquid nitrogen cooled mercury cadmium telluride detector (MCT). The raw exhaust was sampled directly from the tailpipe of the vehicles using a heated PTFE (polytetrafluoroethylene) line and a pumping system (flow: ca. $15 \mathrm{~L} \mathrm{~min}^{-1}, \mathrm{~T}: 121^{\circ} \mathrm{C}$ ) to avoid condensation and/or adsorption of hydrophilic compounds (e.g., $\mathrm{NH}_{3}$ ). The concentrations were acquired at $5 \mathrm{~Hz}$ frequency and resampled to $1 \mathrm{~Hz}$. The overall weight of the system including the batteries needed for the power supply was approximately $80 \mathrm{~kg}$. 
The performance of the portable FTIR during on-road testing was evaluated by comparing the concentrations of $\mathrm{NO}$ and $\mathrm{CO}$ measured by this system to those measured by the PEMS. To assess the measurement of $\mathrm{NH}_{3}$ and $\mathrm{N}_{2} \mathrm{O}$ by the portable FTIR, the DV1 was tested at the JRC's Vehicle Emissions LAboratory (VELA-details of the test cell can be found here [32] under the world harmonized light-duty test procedure (WLTP)). The non-regulated gaseous emissions were measured using a laboratory-grade FTIR (MKS Multigas analyzer 2030-HS, Wilmington, MA, USA) that has been validated in previous studies [31].

The PEMS used during the on-road tests and real traffic conditions in the surroundings of the JRC site was an AVL MOVE system (AVL, Graz, Austria-model 2016). The system measures concentrations of $\mathrm{CO}$ and $\mathrm{CO}_{2}$ from the exhaust gas using a non-dispersive infrared sensor, and $\mathrm{NO}$ and $\mathrm{NO}_{2}$ using a non-dispersive ultra-violet sensor. Furthermore, this PEMS consisted of: a tailpipe attachment, heated exhaust sampling lines, exhaust flow meter (EFM), exhaust gas analyzers, a solid particle counter, data logger connected to vehicle's on-board diagnostics (OBD) port, GPS and a weather station for ambient temperature and humidity measurements. The EFM uses a Pitot tube (installed in a 2" diameter pipe for our tests) to calculate flow rate. The maximum measured exhaust flow rate was $382 \mathrm{~kg} / \mathrm{h}$, which corresponds to $66 \%$ of the maximum range of the flow meter. All relevant emissions data were recorded at a frequency of $10 \mathrm{~Hz}$ and reported at a frequency of $1 \mathrm{~Hz}$.

The portable FTIR used did not include its own EFM. To be able to estimate the mass emissions of the measured pollutants, the exhaust flow measured by the PEMS was used. Hence, $\mathrm{CO}$ and $\mathrm{NO}_{\mathrm{x}}$ measurements from the PEMS were used to synchronize the FTIR signals to those provided by the PEMS. This allowed the use of the exhaust flow measured by the PEMS to estimate the mass emissions of the studied pollutants measured by the FTIR.

The tested gasoline and CNG vehicles complied with pre-RDE EU emission standards. The GV1 and CNG-LCV complied with Euro $6 \mathrm{~b}$ and the GV2 with Euro $6 \mathrm{c}$ standards. All three used a TWC as exhaust after-treatment. Moreover, the GV1 also used a gasoline particle filter (GPF). On the other hand, the diesel vehicles tested complied with Euro 6d-TEMP emission standard, which requires RDE testing for type-approval. The DV1 was equipped with a SCR and the DV2 with LNT and SCR. More details of the tested vehicles are summarized in Table 1.

All vehicles were tested using their applicable laboratory procedures for exhaust emissions, i.e., Worldwide Harmonized Light-Duty Vehicles Test Procedure (WLTP) [EU 2017/1151] [36] for the diesel vehicles (DV1 and DV2) and Type 1 test according to United Nations Economic Commission for Europe (UNECE) Regulation 83 [37] for GV1, GV2 and CNG-LCV (see [32,38] for a complete description of the tests). All vehicles met the Euro 6 limits for all the pollutants. Compliance with the emission limits over the laboratory test procedure was taken as indication that the vehicles were free of malfunctions that could result in abnormally high emissions [39].

During the testing campaign the vehicles were soaked inside a facility at least $4 \mathrm{~h}$ between two consecutive tests; the test performed on the previous day was used as preconditioning for the actual test. Moreover, the air conditioning system was consistently set to $21^{\circ} \mathrm{C}$. Also, when present, the stop/start option was enabled. Finally, the vehicle's battery was not charged between tests.

Gasoline and diesel vehicles were tested fulfilling RDE requirements (see Table 2) along Route-1. CNG-LDV was tested fulfilling RDE requirements (see Table 2) along Route-3. Then, all vehicles were tested on Route-2 (also an RDE compliant route) using a more dynamic driving style, i.e., seeking an increase in the 95th percentile of $\mathrm{v}^{*} \mathrm{a}$ (GV2 was tested on Route-2 on normal driving, not dynamic driving). The higher dynamicity was achieved by faster starts after fully stopping the vehicle at traffic lights or engaging lower gears when using manual transmission. All the dynamic tests were performed respecting the traffic code. 
Table 2. Trips characteristics.

\begin{tabular}{cccc}
\hline & Route-1 & Route-2 Dynamic & Route-3 \\
\hline Trip distance $(\mathrm{km})$ & 94 & 79 & 104 \\
Average trip duration $(\mathrm{min})$ & 112 & 94 & 114 \\
Average urban stop time $(\%)$ & 19 & 23 & 11 \\
Average Urban distance $(\mathrm{km})$ & 37 & 31 & 41 \\
Average Rural distance $(\mathrm{km})$ & 27 & 25 & 29 \\
Average Motorway distance $(\mathrm{km})$ & 30 & 23 & 34 \\
Urban average Speed $(\mathrm{km} / \mathrm{h})$ & 29 & 29 & 34 \\
Average Urban 95th $\mathrm{v}^{* a}\left(\mathrm{~m}^{2} / \mathrm{s}^{3}\right)$ & 13 & 20 & 10 \\
Average Rural 95th $\mathrm{v}^{*} \mathrm{a}\left(\mathrm{m}^{2} / \mathrm{s}^{3}\right)$ & 17 & 29 & 15 \\
Average Motorway 95th $\mathrm{v}^{*} \mathrm{a}\left(\mathrm{m}^{2} / \mathrm{s}^{3}\right)$ & 21 & 29 & 13 \\
Cumulative positive gain $(\mathrm{m} / 100 \mathrm{~km})$ & 820 & 760 & 666 \\
Max trip altitude $(\mathrm{m}$. a.s.l. $)$ & 415 & 300 & 358 \\
\hline
\end{tabular}

The emission factors of regulated and non-regulated pollutants reported in this study were calculated by integrating the total mass emissions measured during the test and dividing the obtained value by the driven distance, as estimated from the GPS velocity signal. These are the so-called 'raw' emissions (without using the weighting function based on $\mathrm{CO}_{2}$ emissions as introduced in the fourth package of the RDE regulation) [EU 2018/1832] [40].

\section{Results and Discussion}

\subsection{Evaluation of the Measurements of the Portable FTIR}

The concentrations of $\mathrm{NO}, \mathrm{CO}$ and $\mathrm{CO}_{2}$ measured with portable FTIR proved to be in very good agreement with the PEMS system during the on-road testing. Figure 1 illustrates some examples of the correlation between the measurements of $\mathrm{NO}, \mathrm{CO}$ and $\mathrm{CO}_{2}$ carried out with the portable FTIR and the AVL MOVE PEMS during on-road testing. The correlation between the two instruments was very good in all cases, with $\mathrm{r}^{2}$ ranging from 0.93 to 0.99 . The largest differences in the measured concentrations were registered for $\mathrm{NO}$ in gasoline and CNG vehicles. Although the portable FTIR underestimated the concentration of NO emissions from GV2 and CNG-LCV by approximately $20 \%$, the difference for the diesel vehicles was between $1 \%$ and $3 \%$. All other pollutants agreed within a difference of $1-8 \%$.

The non-regulated compounds $\left(\mathrm{NH}_{3}, \mathrm{~N}_{2} \mathrm{O}\right.$ and $\left.\mathrm{CH}_{4}\right)$ measured with portable FTIR were also shown to be in good agreement with those measured with the laboratory-grade FTIR during chassis dynamometer tests. Figure 2 illustrates some examples of the correlation between the portable FTIR and the laboratory grade instrument. The measurements $\mathrm{NH}_{3}, \mathrm{~N}_{2} \mathrm{O}$ and $\mathrm{CH}_{4}$ were compared to those of the MKS Multigas analyzer 2030-HS during a WLTP test of DV1. The measurements presented an excellent agreement, with $\mathrm{r}^{2}$ of $0.95,0.96$ and 0.93 for $\mathrm{N}_{2} \mathrm{O}, \mathrm{NH}_{3}$ and $\mathrm{CH}_{4}$, respectively. The good agreement of the emission profile concentrations registered with the portable and lab-grade FTIR is also shown in Figure S2 of the supplementary material.

\subsection{Emissions during On-Road Testing}

Figures 3-5 illustrate $\mathrm{NH}_{3}, \mathrm{~N}_{2} \mathrm{O}, \mathrm{NO}, \mathrm{NO}_{2}, \mathrm{CO}, \mathrm{CH}_{4}$, and $\mathrm{HCHO}$ on-road emissions profiles from the five tested vehicles measured using the portable FTIR. Tables $3-5$ summarize the emissions factors obtained for those pollutants during the two tests performed for each vehicle using two driving styles (except for GV2, which was only driven under normal driving). The tables present emission factors for the whole tests as well as for the different sub-sections (namely, urban, rural and motorway). 


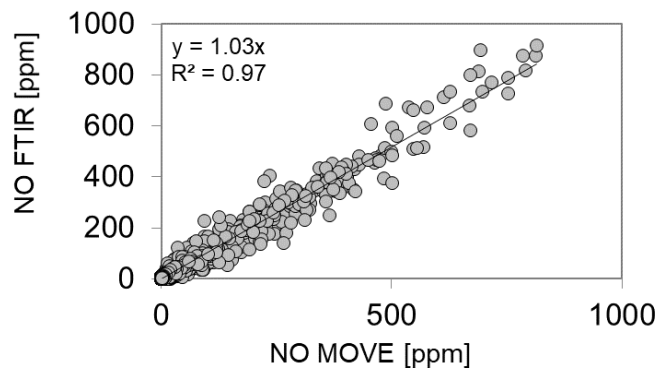

(a)

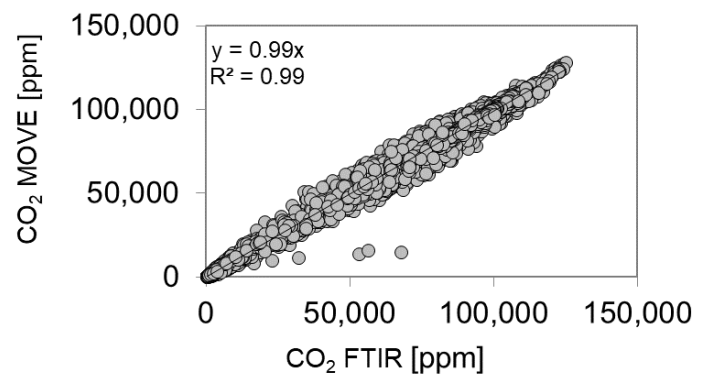

(c)

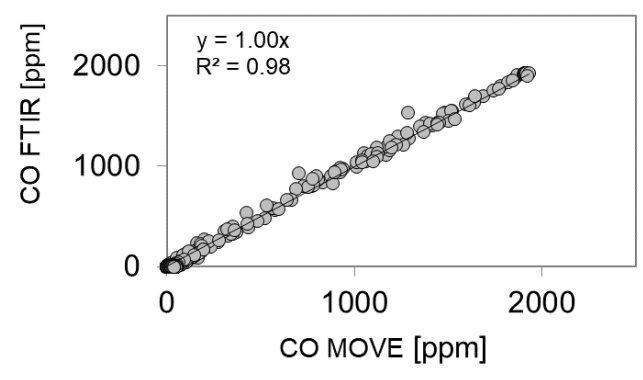

(b)

Figure 1. Correlation between the measurements of (a) $\mathrm{NO},(\mathbf{b}) \mathrm{CO}$, and (c) $\mathrm{CO}_{2}$ carried out with the portable FTIR and the AVL MOVE PEMS during on-road testing of the DV1.

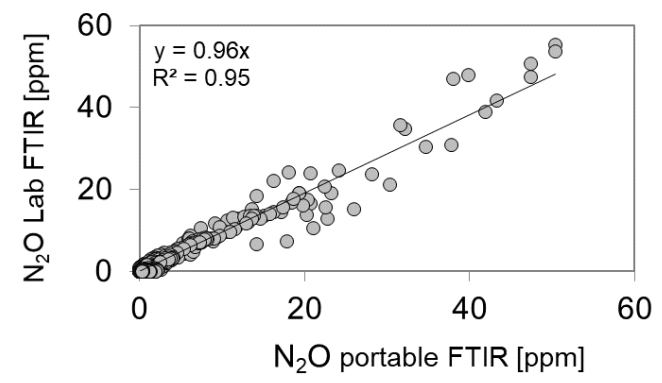

(a)

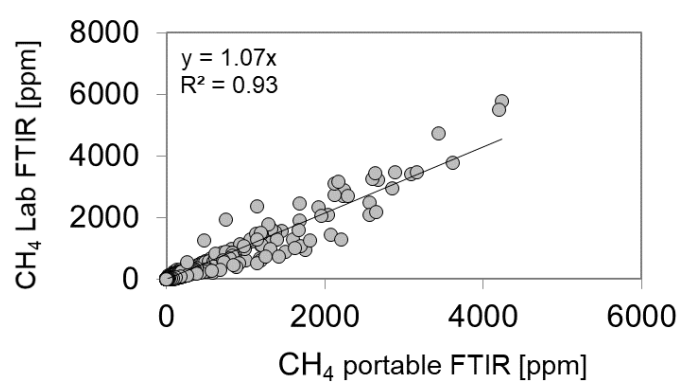

(c)

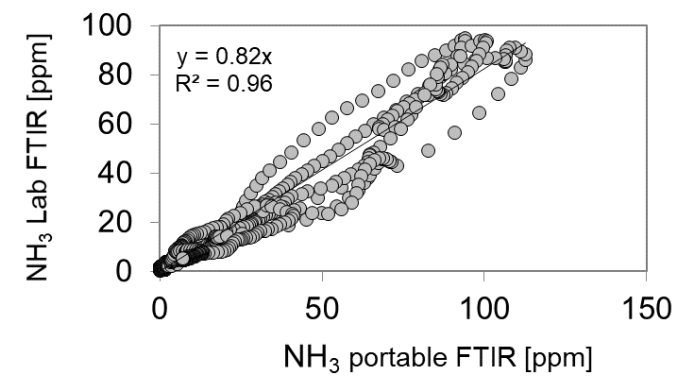

(b)

Figure 2. Correlation of (a) $\mathrm{N}_{2} \mathrm{O},\left(\right.$ b) $\mathrm{NH}_{3}$, and (c) $\mathrm{CH}_{4}$ measured using the portable FTIR and the laboratory-grade instrument. The measurements $\mathrm{NH}_{3}, \mathrm{~N}_{2} \mathrm{O}$ and $\mathrm{CH}_{4}$ were compared to those of the MKS Multigas analyzer 2030-HS during a WLTP test of DV1. 


\subsubsection{On-Road Emissions from the Gasoline Vehicles}

The two studied gasoline vehicles presented relatively low emissions of $\mathrm{NO}$ and $\mathrm{NO}_{2}$ emissions during the on-road tests $(<60 \mathrm{mg} \mathrm{NO} / \mathrm{km}$ ). The exception being GV1 during the dynamic test, which resulted in $195 \mathrm{mg} \mathrm{NO} / \mathrm{km}$ and $10 \mathrm{mg} \mathrm{NO} / \mathrm{km}$. These high $\mathrm{NO}_{x}$ emissions were attributed to a possible regeneration that may have taken place during the rural section (see emission profiles in Figure 3). The vehicle was retested along the same route under dynamic driving, using just the PEMS as the analytic system. In the second test, $\mathrm{NO}_{\mathrm{x}}$ emissions were consistently lower. For more details on the regulated emissions of this vehicle in the laboratory and on-road please see [41]. NO emissions from the gasoline vehicles were also substantially lower than those measured from the diesel vehicles tested (up to $69 \mathrm{mg} / \mathrm{km}$ lower during the Route-1 tests; see Tables 3 and 4).

Table 3. $\mathrm{NH}_{3}, \mathrm{~N}_{2} \mathrm{O}, \mathrm{NO}, \mathrm{NO}_{2}, \mathrm{CO}, \mathrm{CH}_{4}$, and $\mathrm{HCHO}$ emissions factors (mg/km) obtained for the GV1 and the GV2 during the two tests performed for each vehicle along Route- 1 and Route- 2 . The GV1 was tested on a dynamic driving on Route-2. Emission factors $(\mathrm{mg} / \mathrm{km})$ are presented for the complete routes (Comp.), and the urban, rural and motorway (MW) sections.

\begin{tabular}{|c|c|c|c|c|c|c|c|c|}
\hline & \multicolumn{4}{|c|}{ GV1 Route-1 } & \multicolumn{4}{|c|}{ GV1 Route-2 Dynamic } \\
\hline & Comp. & Urban & Rural & MW & Comp. & Urban & Rural & MW \\
\hline $\mathrm{NH}_{3}$ & 49 & 38 & 27 & 85 & 48 & 32 & 48 & 68 \\
\hline $\mathrm{N}_{2} \mathrm{O}$ & 0 & 0 & 0 & 0 & 0 & 0 & 0 & 0 \\
\hline NO & 20 & 27 & 13 & 20 & 195 & 235 & 302 & 25 \\
\hline $\mathrm{NO}_{2}$ & 4 & 9 & 1 & 0 & 10 & 16 & 12 & 0 \\
\hline $\mathrm{CO}$ & 1522 & 957 & 582 & 3116 & 2666 & 1310 & 3261 & 3815 \\
\hline $\mathrm{CH}_{4}$ & 2 & 1 & 0 & 5 & 4 & 1 & 4 & 7 \\
\hline \multirow[t]{3}{*}{ HCHO } & 0 & 1 & 0 & 0 & 0 & 1 & 0 & 0 \\
\hline & \multicolumn{4}{|c|}{ GV2 Route-1 } & \multicolumn{4}{|c|}{ GV2 Route-2 } \\
\hline & Comp. & Urban & Rural & MW & Comp. & Urban & Rural & MW \\
\hline $\mathrm{NH}_{3}$ & 21 & 11 & 10 & 46 & 23 & 11 & 17 & 42 \\
\hline $\mathrm{N}_{2} \mathrm{O}$ & 0 & 0 & 0 & 0 & 0 & 0 & 0 & 0 \\
\hline NO & 25 & 47 & 9 & 14 & 13 & 18 & 3 & 17 \\
\hline $\mathrm{NO}_{2}$ & 5 & 6 & 1 & 7 & 1 & 2 & 0 & 0 \\
\hline $\mathrm{CO}$ & 533 & 159 & 217 & 1383 & 521 & 155 & 252 & 1183 \\
\hline $\mathrm{CH}_{4}$ & 2 & 0 & 0 & 7 & 2 & 0 & 0 & 7 \\
\hline HCHO & 0 & 0 & 0 & 0 & 0 & 0 & 0 & 0 \\
\hline
\end{tabular}

Emissions of $\mathrm{N}_{2} \mathrm{O}$ and $\mathrm{HCHO}$ from the gasoline vehicles were very low, presenting an emission peak above 1 ppm only during the vehicles' cold-start (see Figure 3). In gasoline vehicles, $\mathrm{N}_{2} \mathrm{O}$ is formed on the three-way-catalyst during light-off [9]. Emissions from gasoline passenger cars have been reported to be low, often below $1 \mathrm{mg} \mathrm{N} 2 \mathrm{O} / \mathrm{km}$ during the type-approval cycles [32,42], which is in line with the emissions measured from GV1 and GV2. In line with [32], the emissions of $\mathrm{N}_{2} \mathrm{O}$ from gasoline vehicles were lower than those measured from the tested diesel vehicles (from 4 to $27 \mathrm{mg} / \mathrm{km}$ lower for gasoline than for diesel vehicles; see Tables 3 and 4). On the other hand, HCHO emissions, which result from incomplete combustion of the fuel [43], were emitted before the catalyst light-off, and then dropped below limit of detection of the instrument for both vehicles (see Figure 2). Emission factors during the urban section were in line with those reported for Euro 6 gasoline vehicles tested with E5 gasoline over the Worldwide Harmonized Light-Duty Vehicles Test Cycle (WLTC) [44] and also with other spark ignition vehicles tested with E5 over the WLTC and whose HCHO emissions were measured by means of FTIR [45] and other techniques [46].

On-road $\mathrm{CH}_{4}$ emission factors from gasoline vehicles were $2 \mathrm{mg} / \mathrm{km}$ during moderate driving and $4 \mathrm{mg} / \mathrm{km}$ for the dynamic test performed with GV1. Interestingly, the highest emissions were measured during the motorway section of the test $(7 \mathrm{mg} \mathrm{CH} / \mathrm{km}) . \mathrm{CH}_{4}$ emissions were lower in all cases than the limit currently in forc in the USA $(18.8 \mathrm{mg} / \mathrm{km}$ over the Federal Test Procedure (FTP)). 
The similar emission $\mathrm{CO}$ and $\mathrm{CH}_{4}$ emission profiles (see Figure 3) suggests that the TWC was not able to fully control $\mathrm{CH}_{4}$ emissions during transient operation as a result of temporary fuel mixture enrichment after catalyst light-off. Nonetheless, $\mathrm{CH}_{4}$ emissions were relatively low during all sections of the on-road tests.

Table 4. $\mathrm{NH}_{3}, \mathrm{~N}_{2} \mathrm{O}, \mathrm{NO}, \mathrm{NO}_{2}, \mathrm{CO}, \mathrm{CH}_{4}$, and $\mathrm{HCHO}$ emissions factors $(\mathrm{mg} / \mathrm{km})$ obtained for the DV1 and the DV2 during the two tests performed for each vehicle along Route-1 and Route-2. Both vehicles were tested on a dynamic driving on Route-2. Emission factors $(\mathrm{mg} / \mathrm{km})$ are presented for the complete routes (Comp.), and the urban, rural and motorway (MW) sections.

\begin{tabular}{|c|c|c|c|c|c|c|c|c|}
\hline & \multicolumn{4}{|c|}{ DV1 Route-1 } & \multicolumn{4}{|c|}{ DV1 Route-2 Dynamic } \\
\hline & Comp. & Urban & Rural & MW & Comp. & Urban & Rural & MW \\
\hline $\mathrm{NH}_{3}$ & 17 & 32 & 13 & 3 & 2 & 3 & 1 & 2 \\
\hline $\mathrm{N}_{2} \mathrm{O}$ & 5 & 11 & 3 & 1 & 4 & 6 & 2 & 2 \\
\hline NO & 84 & 63 & 66 & 126 & 308 & 218 & 274 & 467 \\
\hline $\mathrm{NO}_{2}$ & 6 & 3 & 6 & 12 & 19 & 11 & 13 & 36 \\
\hline $\mathrm{CO}$ & 13 & 30 & 0 & 2 & 10 & 13 & 4 & 12 \\
\hline $\mathrm{CH}_{4}$ & 0 & 0 & 0 & 0 & 0 & 1 & 0 & 0 \\
\hline \multirow[t]{3}{*}{ HCHO } & 0 & 0 & 0 & 0 & 0 & 0 & 0 & 0 \\
\hline & \multicolumn{4}{|c|}{ DV2 Route-1 } & \multicolumn{4}{|c|}{ DV2 Route-2 Dynamic } \\
\hline & Comp. & Urban & Rural & MW & Comp. & Urban & Rural & MW \\
\hline $\mathrm{NH}_{3}$ & 1 & 0 & 0 & 1 & 0 & 0 & 0 & 1 \\
\hline $\mathrm{N}_{2} \mathrm{O}$ & 27 & 40 & 31 & 13 & 19 & 30 & 20 & 9 \\
\hline NO & 82 & 79 & 43 & 120 & 286 & 272 & 275 & 310 \\
\hline $\mathrm{NO}_{2}$ & 13 & 9 & 10 & 18 & 40 & 35 & 36 & 48 \\
\hline $\mathrm{CO}$ & 0 & 5 & 0 & 0 & 0 & 0 & 0 & 0 \\
\hline $\mathrm{CH}_{4}$ & 21 & 27 & 21 & 15 & 8 & 8 & 10 & 7 \\
\hline НСНО & 0 & 0 & 0 & 0 & 0 & 0 & 0 & 0 \\
\hline
\end{tabular}

$\mathrm{NH}_{3}$ emissions from the gasoline cars varied from $21 \mathrm{mg} \mathrm{NH} / \mathrm{km}$ (GV2) to $49 \mathrm{mg} \mathrm{NH}_{3} / \mathrm{km}$ (GV1). Both vehicles presented emissions along all three sections of the routes. $\mathrm{NH}_{3}$ emission factors were highest on the motorway section for both vehicles and under the two driving styles. The emissions during the motorway section reached $85 \mathrm{mg} \mathrm{NH}_{3} / \mathrm{km}$ for GV1 and $46 \mathrm{mg} \mathrm{NH}_{3} / \mathrm{km}$ for GV2. On the other hand, $\mathrm{NH}_{3}$ emissions during the urban section were 38 and $32 \mathrm{mg} \mathrm{NH} / \mathrm{km}$ for $\mathrm{GV} 1$ (for the normal and dynamic test respectively) and $11 \mathrm{mg} \mathrm{NH}_{3} / \mathrm{km}$ for GV2. Staying with the results presented by Link et al. [28], these $\mathrm{NH}_{3}$ emissions when reacted with $\mathrm{HNO}_{3}$ present in the atmosphere would result in approximately $38 \mathrm{mg} \mathrm{PM} 2.5 / \mathrm{km}$ for GV1 and approximately $11 \mathrm{mg} \mathrm{PM} 2.5 / \mathrm{km}$ for GV2. It should be noted that tailpipe PM limit for passenger vehicles in the EU is $4.5 \mathrm{mg} / \mathrm{km}$. Hence, these vehicles may lead to the formation of more secondary inorganic aerosols than the PM primary emissions allowed in the laboratory test. In a recent study Simonen et al. [47] showed that the dominant part of aged aerosol mass from two gasoline vehicles was inorganic, including ammonium nitrate and sulphate.

The obtained $\mathrm{NH}_{3}$ emissions factors were in line with those recently reported in tunnel and laboratory studies worldwide [23,48,49]. However, they were 2.6 to 9.8 times higher than the on-road $\mathrm{NH}_{3}$ emissions from a Euro $6 \mathrm{~b}$ gasoline direct injection (GDI) vehicle presented in a previous work [31].

The two tested gasoline vehicles presented higher molar-based $\mathrm{NH}_{3}$ emissions (mol/ $\mathrm{km}$ units) than $\mathrm{NO}_{\mathrm{x}}$ emissions. This result supports previous studies that have arrived at the same conclusion by measuring $\mathrm{NH}_{3}$ emissions from gasoline vehicles using remote sensing [16] and chassis dynamometer testing [8]. If one considers that the atom of nitrogen contained in the $\mathrm{NH}_{3}$ emitted by these vehicles comes from the engine-out $\mathrm{NO}$ ( $\mathrm{NO}$ is the precursor of $\mathrm{NH}_{3}$ in gasoline cars, see [50]), and calculate total $\mathrm{NO}_{\mathrm{x}}$ emissions including $\mathrm{NH}_{3}$ s nitrogen, the GV1 and the GV2 would have presented $168 \mathrm{mg}$ $\mathrm{NO}_{\mathrm{x}} / \mathrm{km}$ and $92 \mathrm{mg} \mathrm{NO} / \mathrm{km}$ on the Route-1. 
$\mathrm{NH}_{3}$ emissions from spark ignition vehicles have been indicated to be correlated with $\mathrm{CO}$ emissions, as the two pollutants are emitted during fuel rich events [6,51]. In this line, GV2, which resulted in lower $\mathrm{NH}_{3}$ emissions than GV1, also presented lower $\mathrm{CO}$ emissions $(533 \mathrm{mg} / \mathrm{km}$ ) than GV1 $(1522 \mathrm{mg} / \mathrm{km})$. Nonetheless, while $\mathrm{NH}_{3}$ emissions from GV1 during moderate driving (Route-1) were comparable to those measured during dynamic driving, $\mathrm{CO}$ emissions were 1.8 times higher during dynamic driving $(2666 \mathrm{mg} / \mathrm{km})$ compared to moderate driving. Both vehicles always presented the highest emissions of $\mathrm{CO}$ during motorway operation. This suggests that gasoline vehicles equipped with TWC can result in high emissions of CO not only during cold start but also after catalyst light-off. High CO emissions from gasoline vehicles during dynamic driving have recently been reported during on-road and on-dyno RDE tests [52,53]. Moreover, Kelly and Groblicki already reported this operation in the U.S. in 1993 [54]. Currently, the U.S. code of federal regulation limits vehicle enrichment [U.S. 40 CFR 86. 1811-17] [26].
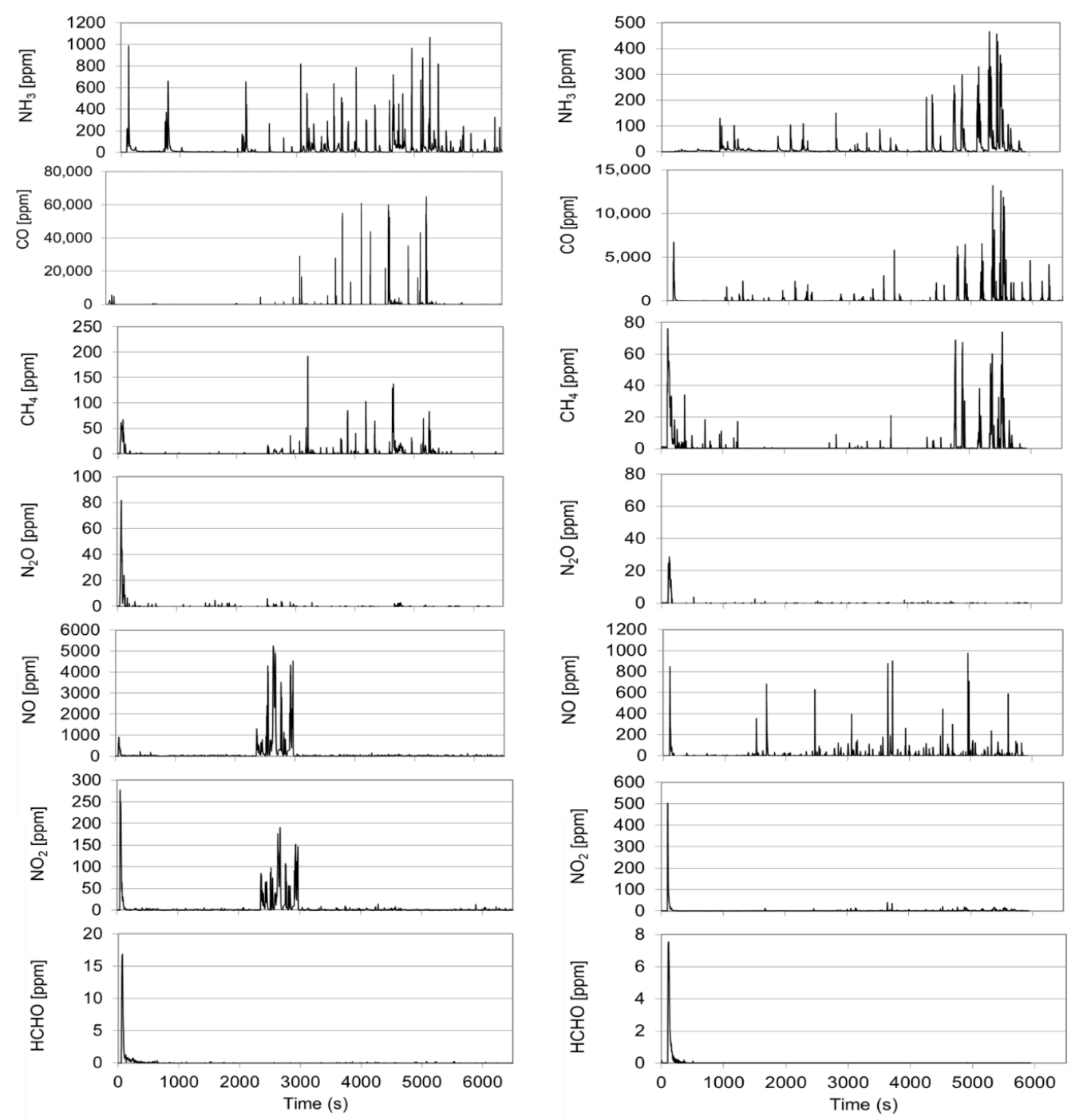

(GV1)

(GV2)

Figure 3. $\mathrm{NH}_{3}, \mathrm{~N}_{2} \mathrm{O}, \mathrm{NO}, \mathrm{NO}_{2}, \mathrm{CO}, \mathrm{CH}_{4}$, and $\mathrm{HCHO}$ on-road emissions profiles registered for the GV1 during the dynamic test on Route-2 (left panels) and for the GV2 during the RDE test on Route-1 (right panels). 


\subsubsection{On-Road Emissions from the Diesel Vehicles}

Table 4 summarizes the emission factors obtained from the two diesel vehicles (DV1 and DV2) tested on moderate and dynamic driving along the two RDE compliant routes. Aiming at reducing its $\mathrm{NO}_{\mathrm{x}}$ emissions, the DV1 was equipped with an exhaust gas recirculation (EGR) + DOC + SCR system. The DV2 was equipped with a combination of EGR + DOC + LNT + SCR for this purpose.

$\mathrm{NO}_{\mathrm{x}}$ emissions from the two Euro 6d-TEMP diesel vehicles, DV1 and DV2, during the RDE-compliant test (Route-1) were below Euro 6d-TEMP on-road emission requirement $(80 \mathrm{mg} / \mathrm{km}$ $\times 2.1$ conformity factor), for the complete and the urban sections (see Table 4). The highest $\mathrm{NO}_{\mathrm{x}}$ emission factors were registered on the motorway section for the two diesel vehicles under the two studied conditions.

In the dynamic tests, $\mathrm{NO}_{\mathrm{x}}$ emissions were $\sim 3.5$ times higher than in the RDE compliant tests. Higher emissions during dynamic operation compared to "normal" driving have previously been reported for Euro $6 \mathrm{~b}$ diesel vehicles equipped with SCR and LNT systems [55]. Although $\mathrm{NO}_{x}$ emissions from vehicles type-approved using RDE have been improved overall, the relatively high emissions measured from the two Euro 6d-TEMP diesel vehicles during dynamic driving and on the motorway section illustrate that there are still operating conditions that could be improved.

$\mathrm{NH}_{3}$ emissions from DV1 were higher $(2 \mathrm{mg} \mathrm{NH} / 3 / \mathrm{km}$ on Route- 2 driven dynamically and $17 \mathrm{mg}$ $\mathrm{NH}_{3} / \mathrm{km}$ on Route-1, which was RDE compliant) than those measured from DV2 (max. $1 \mathrm{mg} \mathrm{NH}_{3} / \mathrm{km}$ ). The DV1's $\mathrm{NH}_{3}$ emissions during Route- $1(17 \mathrm{mg} / \mathrm{km})$ were comparable to those measured from GV2 over the same route $(21 \mathrm{mg} / \mathrm{km}) . \mathrm{NH}_{3}$ emissions from DV1 on Route-1 were highest on the urban section of the test, reaching $32 \mathrm{mg} \mathrm{NH} / / \mathrm{km}$ and lowest $\left(3 \mathrm{mg} \mathrm{NH}_{3} / \mathrm{km}\right.$ ) on the motorway section. This indicates that new diesel vehicles could become a new source of $\mathrm{NH}_{3}$ in urban areas, which until now have been dominated by gasoline vehicles [21-25]. Owing to the low $\mathrm{NH}_{3}$ emissions measured from DV2 on all tested conditions, it is assumed that, in addition to LNT and SCR, it was also equipped with an ammonia slip catalyst (ASC). Similar efficiency at removing $\mathrm{NH}_{3}$ using ASC was recently shown for a Euro 5 and a Euro 6 diesel vehicle retrofitted with a solid ammonia reduction system $[55,56]$.

$\mathrm{NH}_{3}$ emissions from DV1 on the RDE-compliant Route-1 were 2.4-5.7 times higher than those reported from an SCR-equipped Euro $6 \mathrm{~b}$ diesel vehicle tested on-road on an RDE compliant route [31]. Nonetheless, DV1 resulted in 4.3-5 times lower $\mathrm{NO}_{\mathrm{x}}$ emissions than the Euro $6 \mathrm{~b}$ vehicle (389-448 mg $\mathrm{NO}_{\mathrm{x}} / \mathrm{km}$ ). Hence, although $\mathrm{NO}_{\mathrm{x}}$ emissions from DV1 are lower than those commonly reported for Euro $6 \mathrm{~b}$ vehicles [57], its $\mathrm{NH}_{3}$ emissions are higher. This indicates that diesel vehicles could become an important source of $\mathrm{NH}_{3}$ in urban areas.

Interestingly, $\mathrm{NH}_{3}$ emissions from DV1 during a regeneration event reached concentrations above 2000 ppm (see Figure S3 in the supplementary material). This concentration was one order of magnitude higher than the maximum concentration measured during the other tests performed with the same vehicle.

The DV1 resulted in $327 \mathrm{mg} \mathrm{NO} / \mathrm{km}$ on the dynamic test performed on Route-2, which in turn emitted $2 \mathrm{mg} \mathrm{NH} / \mathrm{km}$. Moreover, for the DV1 (equipped only with SCR) the highest $\mathrm{NH}_{3}$ emissions were obtained along the lowest $\mathrm{NO}_{\mathrm{x}}$ emissions (see Table 4). A similar trend (higher $\mathrm{NO}_{\mathrm{x}}$ emissions on dynamic tests compared to RDE-compliant test) and similar emission factors were obtained for DV2. In both cases, these $\mathrm{NO}_{x}$ emissions were achieved with low emissions of $\mathrm{NH}_{3}$ (max. $1 \mathrm{mg} \mathrm{NH} / \mathrm{km}$ ).

The two diesel vehicles, fueled with $\mathrm{B} 7 \mathrm{diesel}$, presented very low $\mathrm{HCHO}$ emissions that were measured by the portable FTIR only at the vehicles' cold start (see Figure 4). In line with the usual behavior observed for diesel vehicles, $\mathrm{CO}$ emissions were also very low on all the tests performed. The highest CO emission factors for DV1 $(30 \mathrm{mg} \mathrm{CO} / \mathrm{km})$ and DV2 $(5 \mathrm{mg} \mathrm{CO} / \mathrm{km})$ were measured on the urban section of Route-1. Emissions of $\mathrm{CO}$ were mainly concentrated at the cold start. The DV2, equipped with DOC, SCR and LNT systems also present some CO peaks typical of the LNT regeneration episodes (see Figure 4). During those LNT regeneration events, other pollutants such as $\mathrm{CH}_{4}$ and $\mathrm{N}_{2} \mathrm{O}$ were emitted. $\mathrm{CH}_{4}$ emissions from the DV2 ranged from $8 \mathrm{mg} \mathrm{CH} / \mathrm{km}$ on the dynamically driven Route- 2 and $21 \mathrm{mg} \mathrm{CH} / \mathrm{km}$ on Route-1. Hence, $\mathrm{CH}_{4}$ emissions from the DV2 on 
Route- 1 were higher than those measured from the gasoline vehicles (see Tables 3 and 4) and slightly higher than the limit allowed in the USA under the FTP $(18.8 \mathrm{mg} / \mathrm{km})$.
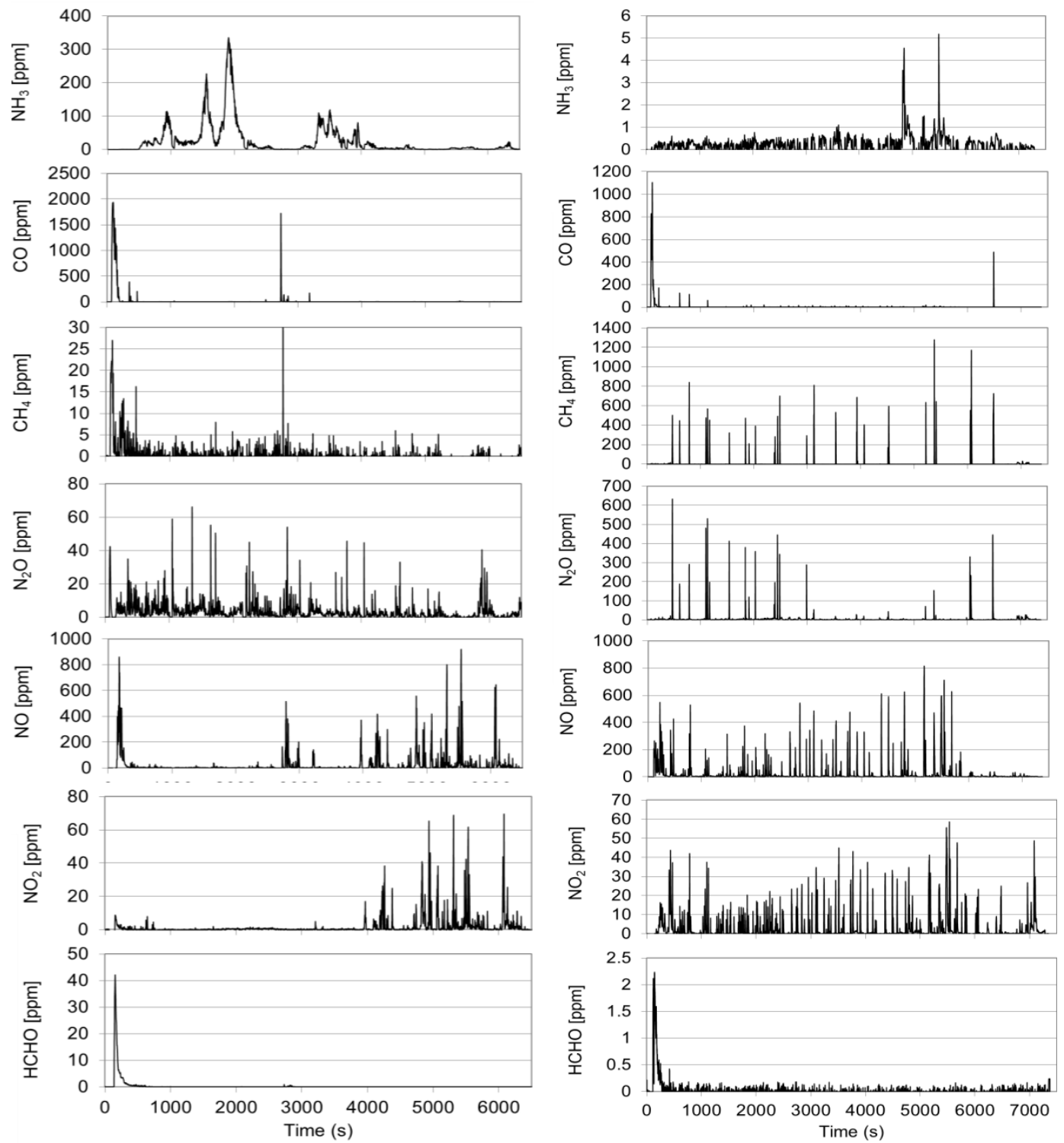

(DV1)

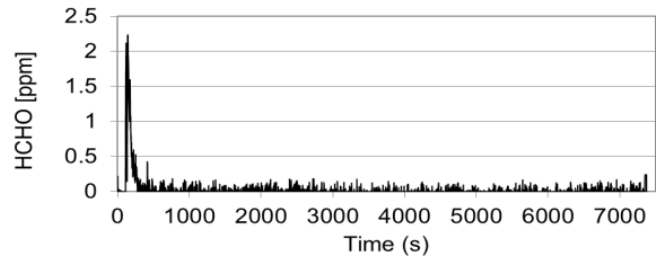

(DV2)

Figure 4. $\mathrm{NH}_{3}, \mathrm{~N}_{2} \mathrm{O}, \mathrm{NO}, \mathrm{NO}_{2}, \mathrm{CO}, \mathrm{CH}_{4}$, and $\mathrm{HCHO}$ on-road emissions profiles registered during the RDE test on route 1 for the DV1 (left panels) and for the DV2 (right panels).

The emissions of $\mathrm{N}_{2} \mathrm{O}$ ranged from $19 \mathrm{mg} \mathrm{N} \mathrm{N}_{2} \mathrm{O} / \mathrm{km}$ (Route-2-dynamic) to $27 \mathrm{mg} \mathrm{N} \mathrm{N}_{2} \mathrm{O} / \mathrm{km}$ (Route- 1 ) throughout the entire tests. These emissions were 3 to 4 times higher than the current USA limit ( $6.3 \mathrm{mg} / \mathrm{km}$ over the FTP) and 1.5 times higher than the China 6 standard ( $20 \mathrm{mg} / \mathrm{km}$ over the WLTC). These on-road emission factors measured on the RDE-compliant route (Route-1) were higher than those measured from the GV1, GV2 and CNG-LCV. They were also higher than those measured from an LNT-equipped Euro $6 \mathrm{~b}$ diesel vehicle $\left(12 \pm 3 \mathrm{mg} \mathrm{N} \mathrm{N}_{2} \mathrm{O} / \mathrm{km}\right.$ and $\left.14 \pm 2 \mathrm{mg} \mathrm{CH} / \mathrm{km}\right)$ tested over the WLTC at $23{ }^{\circ} \mathrm{C}$ [58].

Since $\mathrm{CH}_{4}$ and $\mathrm{N}_{2} \mathrm{O}$ are green-house gases, it is possible to calculate their $\mathrm{CO}_{2}$ emission factor equivalency $\left(\mathrm{g} \mathrm{CO}_{2}\right.$ eqv $\left./ \mathrm{km}\right)$ using their emissions factors and their global warming potential (GWP). $\mathrm{CH}_{4}$ is a green-house gas with a short lifetime. Therefore, we use the $\mathrm{CH}_{4} \mathrm{GWP}$ over 20 years (84-87). 
Hence, $\mathrm{CO}_{2}$ g equivalent $/ \mathrm{km}$ from DV2 related to $\mathrm{CH}_{4}$ emissions ranged from 0.8 to $1.8 \mathrm{~g} \mathrm{CO}_{2} \mathrm{eqv} / \mathrm{km}$. Those related to $\mathrm{N}_{2} \mathrm{O}$ emissions (calculated using $\mathrm{N}_{2} \mathrm{O}^{\prime}$ s GWP over a 100-year timescale 265-298) ranged from 5 to $8 \mathrm{~g} \mathrm{CO}_{2}$ eqv $/ \mathrm{km}$.

Therefore, although the after-treatment system used by the DV2 (DOC+LNT+SCR and possibly an ASC) allow the vehicle to meet the $\mathrm{NO}_{x}$ requirements under real-world driving conditions, it resulted in emissions of up to $9.8 \mathrm{~g} \mathrm{CO}_{2}$ eqv $/ \mathrm{km}$ in the form of GHGs that are not regulated with respect to vehicle emissions in Europe.

The DV1, equipped with a DOC and SCR, presented very low $\mathrm{CH}_{4}$ emissions (see Table 4) and the emissions of $\mathrm{N}_{2} \mathrm{O}$ were lower than those measured from the DV2, ranging from $4 \mathrm{mg} \mathrm{N} \mathrm{N}_{2} \mathrm{O} / \mathrm{km}$ (1-1.2 $\mathrm{g} \mathrm{CO}_{2}$ eqv $\left./ \mathrm{km}\right)$ to $5 \mathrm{mg} \mathrm{N} \mathrm{N}_{2} \mathrm{O} / \mathrm{km}\left(1.3-1.5 \mathrm{~g} \mathrm{CO}_{2}\right.$ eqv $\left./ \mathrm{km}\right)$. The $\mathrm{N}_{2} \mathrm{O}$ emissions from DV1 were lower than the China 6 and USA limits. These $\mathrm{N}_{2} \mathrm{O}$ and $\mathrm{CH}_{4}$ emissions were in line with those from a SCR-equipped Euro $6 \mathrm{~b}$ diesel vehicle tested over the WLTC at $23{ }^{\circ} \mathrm{C}(1 \mathrm{mg} \mathrm{CH} / \mathrm{km}$ and $7 \mathrm{mg}$ $\left.\mathrm{N}_{2} \mathrm{O} / \mathrm{km}\right)[58]$.

In summary, $\mathrm{NO}_{x}$ emissions from the two Euro 6d-TEMP diesel vehicles, DV1 and DV2, during the RDE-compliant tests (Route-1) were below the Euro 6d-TEMP on-road emission requirement $(80 \mathrm{mg} / \mathrm{km} \times 2.1$ conformity factor) for the complete route and for the urban sections. The DV1 met the $\mathrm{NO}_{x}$ requirements using a DOC + SCR and the DV2 using a combination of DOC + LNT + SCR and possibly an ASC. Due to the intensive use of the SCR, and the high production of $\mathrm{NH}_{3}$, to reduce the $\mathrm{NO}_{x}$ emissions, and in absence of an ammonia oxidation catalyst, the DV1 emitted $17 \mathrm{mg} \mathrm{NH} / / \mathrm{km}$ (32 $\mathrm{mg} \mathrm{NH}_{3} / \mathrm{km}$ in the urban section). In turn, these $\mathrm{NH}_{3}$ emissions will potentially react in the atmosphere to produce approximately $17 \mathrm{mg} \mathrm{PM} 2.5 / \mathrm{km}[28]$.

On the other hand, the DV2 did not result in high $\mathrm{NH}_{3}$ emissions (max. $1 \mathrm{mg} \mathrm{NH}_{3} / \mathrm{km}$ ), possibly thanks to the use of an ASC. However, the intensive use of the LNT to reduce the $\mathrm{NO}_{x}$ emissions and the presence other catalyzed after-treatments (SCR, DOC and ASC) lead to the emissions of up $9.8 \mathrm{~g}$ $\mathrm{CO}_{2}$ eqv $/ \mathrm{km}$ in the form of GHGs that are not regulated with respect to vehicle emissions in Europe.

\subsubsection{On-Road Emissions from the CNG Light-Commercial Vehicle}

The CNG-LCV's emission factors obtained on an RDE-compliant test (Route-3) and on the RDE route driven dynamically (Route-2) are summarized in Table 5. The emissions of $\mathrm{HCHO}$ and $\mathrm{N}_{2} \mathrm{O}$ from the CNG-LCV were low. These emissions were only present until the catalyst light-off (see Figure 5). $\mathrm{HCHO}$ from the CNG-LCV were comparable to the light-duty vehicles tested (both gasoline and diesel). $\mathrm{N}_{2} \mathrm{O}$ emissions were comparable to the GV1 and GV2, and were much lower than those measured from the diesel vehicles (see Tables 3-5). Although the CNG-LCV and the gasoline vehicles used different fuels, their $\mathrm{N}_{2} \mathrm{O}$ emission profiles were also similar. These similarities with the gasoline vehicles come from use of the same after-treatment system, the TWC. Rašić et al. [59] recently reported the possibility high and frequent emissions of $\mathrm{N}_{2} \mathrm{O}$ from a dual-fuel $\mathrm{CNG} /$ gasoline Euro 5 light duty vehicle tested on $\mathrm{CNG}$ on the road. This work highlighted the possibility of a cross-interference between $\mathrm{N}_{2} \mathrm{O}$ and $\mathrm{CO}$ in the nondispersive infrared (NDIR) that was used for the measurement of $\mathrm{CO}$. The measurements of $\mathrm{N}_{2} \mathrm{O}$ and $\mathrm{CO}$ performed with the portable FTIR compared with the measurement of $\mathrm{CO}$ with the NDIR installed in our PEMS indicate that there was no cross-interference in the PEMS system used in our study (Figure S4 supplementary material).

CO emissions ranged from $399 \mathrm{mg} \mathrm{CO} / \mathrm{km}$ on the dynamic test (Route-2) to $418 \mathrm{mg} \mathrm{CO} / \mathrm{km}$ on the RDE-compliant test. These emissions are approximately 3.5 times higher than those measured on-road from a series of Euro $6 \mathrm{~b}$ CNG light commercial vehicles [24].

$\mathrm{NO}_{\mathrm{x}}$ emissions were high on the two tests performed. They ranged from $386 \mathrm{mg} \mathrm{NO} / \mathrm{km}$ during the dynamic test, to $424 \mathrm{mg} \mathrm{NO} / \mathrm{km}$ during the RDE-compliant test. In both cases, the highest $\mathrm{NO}_{\mathrm{x}}$ emissions were measured during the urban section (up to $837 \mathrm{mg} \mathrm{NO} / \mathrm{km}$ ). High $\mathrm{NO}_{\mathrm{x}}$ emissions were in fact presented by Jahirul et al. [60] as the main concern when using CNG. High $\mathrm{NO}_{\mathrm{x}}$ emissions from a CNG-fueled engine have been explained to result from high cylinder temperature, and lean air-to-fuel ratios [59]. However, the engine used in the CNG-LCV should have been a stoichiometric 
engine, otherwise TWC would not work. The efficiency of the TWC is more sensitive to the air fuel ratio when running on CNG relative to gasoline, as there are far fewer products of incomplete combustion $-\mathrm{H}_{2}, \mathrm{NMHC}$ and $\mathrm{CO}$, needed in the TWC to reduce $\mathrm{NO}_{x}$ - with $\mathrm{CNG}$ than with gasoline. Therefore, the high $\mathrm{NO}_{x}$ emissions could be attributed to sub-standard engineering, not reflecting the best available technology.
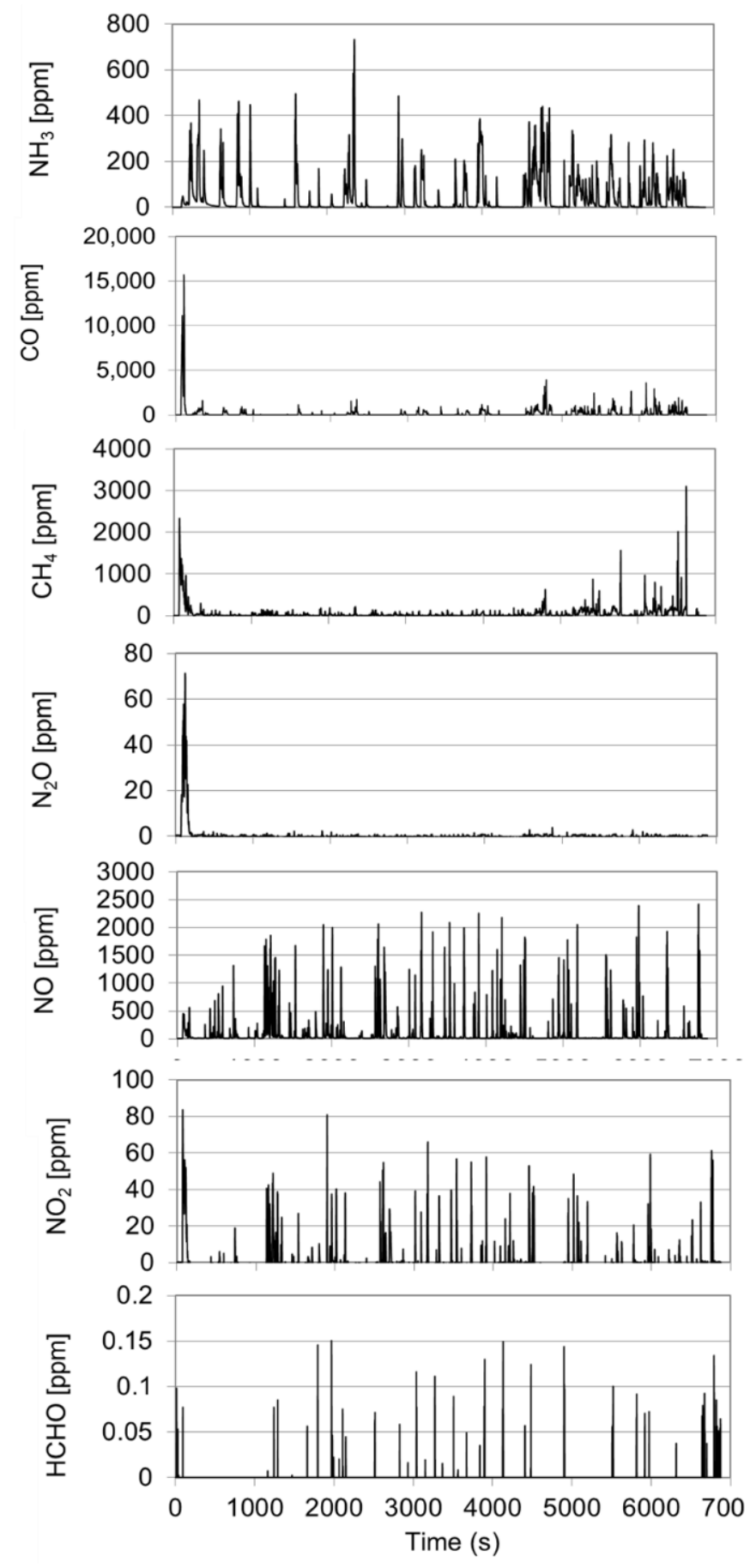

\section{(CNG-LCV)}

Figure 5. $\mathrm{NH}_{3}, \mathrm{~N}_{2} \mathrm{O}, \mathrm{NO}, \mathrm{NO}_{2}, \mathrm{CO}, \mathrm{CH}_{4}$, and $\mathrm{HCHO}$ on-road emissions profiles registered during the RDE test on Route-3 for the CNG-LCV. 
Table 5. $\mathrm{NH}_{3}, \mathrm{~N}_{2} \mathrm{O}, \mathrm{NO}, \mathrm{NO}_{2}, \mathrm{CO}, \mathrm{CH}_{4}$, and $\mathrm{HCHO}$ emissions factors $(\mathrm{mg} / \mathrm{km})$ obtained for the CNG-LCV during the two tests performed for each vehicle along Route-3 and Route- 2 . The vehicle was tested through dynamic driving on Route-2. Emission factors $(\mathrm{mg} / \mathrm{km})$ are presented for the complete routes (Comp.), as well as the urban, rural and motorway (MW) sections.

\begin{tabular}{ccccccccc}
\hline & \multicolumn{3}{c}{ CNG-LCV Route-3 } & \multicolumn{3}{c}{ CNG-LCV Route-2 Dynamic } \\
\hline & Comp. & Urban & Rural & MW & Comp. & Urban & Rural & MW \\
\hline $\mathbf{N H}_{\mathbf{3}}$ & 66 & 46 & 90 & 71 & 62 & 38 & 75 & 82 \\
$\mathbf{N}_{\mathbf{2}} \mathbf{O}$ & 1 & 3 & 0 & 0 & 0 & 1 & 0 & 0 \\
$\mathbf{N O}$ & 405 & 799 & 172 & 50 & 372 & 720 & 244 & 37 \\
$\mathbf{N O}_{\mathbf{2}}$ & 19 & 28 & 12 & 11 & 14 & 24 & 9 & 6 \\
$\mathbf{C O}$ & 418 & 327 & 369 & 601 & 399 & 202 & 344 & 698 \\
$\mathbf{C H}$ & 75 & 76 & 21 & 126 & 72 & 55 & 31 & 127 \\
$\mathbf{H C H O}$ & 0 & 0 & 0 & 0 & 0 & 0 & 0 & 0 \\
\hline
\end{tabular}

High emissions of $\mathrm{NO}_{x}$ from a series of Euro $6 \mathrm{~b}$ CNG light commercial vehicles were also reported in a previous on-road study [24]. Nonetheless, the CNG-LCV's $\mathrm{NO}_{x}$ emissions obtained during Route-3 and Route-2 were two times higher than those reported in Vojtíšek-Lom et al. [35].

The CNG-LCV also resulted in high $\mathrm{NH}_{3}$ emissions. These emissions ranged from $62 \mathrm{mg} \mathrm{NH} / \mathrm{km}$ (Route-2 dynamic) to $69 \mathrm{mg} \mathrm{NH} / \mathrm{km}$ (Route-3). The highest $\mathrm{NH}_{3}$ emissions on the RDE-compliant route were found during the rural section $(90 \mathrm{mg} \mathrm{NH} / 3 \mathrm{~km})$ and in the dynamic test during the motorway section $\left(82 \mathrm{mg} \mathrm{NH} / \mathrm{km}\right.$ ). Nonetheless, $\mathrm{NH}_{3}$ emissions were also high during the urban section (46 and $38 \mathrm{mg} \mathrm{NH}_{3} / \mathrm{km}$ on Route- 3 and Route-2, respectively). With respect to gasoline vehicles, $\mathrm{NH}_{3}$ is formed on the TWC present in the CNG-LCV. These emissions are six times higher than those previously reported for from a series of Euro $6 \mathrm{~b}$ dual fuel (CNG/gasoline) light commercial vehicles tested on-road [35].

Finally, $\mathrm{CH}_{4}$ emissions from the CNG-LCV ranged from $72 \mathrm{mg} \mathrm{CH} / \mathrm{km}$ (Route- 2 dynamic) to $75 \mathrm{mg} \mathrm{CH} / 4 \mathrm{~km}$ (Route-3 RDE-compliant). Hence, in terms of $\mathrm{CO}_{2}$ equivalent emissions, the emissions of $\mathrm{CH}_{4}$ from the CNG-LCV represent up to $6.5 \mathrm{~g} \mathrm{CO}_{2}$ eqv/km (GWP over 20 years 84-87). The CNG-LCV resulted in the highest $\mathrm{CH}_{4}$ emissions on the motorway section (126 and $127 \mathrm{mg} \mathrm{CH} / \mathrm{km}$ on Route- 3 and Route-2, respectively). The $\mathrm{CH}_{4}$ emissions were 4 times higher than those previously reported for a series of dual fuel (CNG/gasoline) LCV [35].

\section{Conclusions}

The current study investigates the real-world driving emissions of pollutants that are not currently regulated in Europe from a series of recent vehicles available in the EU market including gasoline, diesel and CNG vehicles. The list of pollutants includes $\mathrm{NH}_{3}, \mathrm{~N}_{2} \mathrm{O}, \mathrm{CH}_{4}$ and $\mathrm{HCHO}$. The study also shows the emissions of $\mathrm{NH}_{3}$ and $\mathrm{N}_{2} \mathrm{O}$ from diesel vehicles that were designed to meet $\mathrm{NO}_{x}$ requirements during RDE testing. The measurements were performed using a portable FTIR that made it possible to measure these gaseous pollutants, as well as those currently regulated in vehicle exhaust in Europe.

The concentrations of gaseous compounds measured on-road with portable FTIR and the AVL MOVE PEMS (NO, $\mathrm{CO}$ and $\mathrm{CO}_{2}$ ) were very well correlated. The deviation of the measured concentrations varied between $1 \%$ and $8 \%$, and $\mathrm{r}^{2}$ ranged from 0.93 to 0.99 . When used in the vehicle emissions laboratory test, the concentrations of $\mathrm{NH}_{3}, \mathrm{~N}_{2} \mathrm{O}$ and $\mathrm{CH}_{4}$ measured with the portable FTIR also correlated very well with those measured using a laboratory grade FTIR. The $\mathrm{r}^{2}$ for $\mathrm{N}_{2} \mathrm{O}, \mathrm{NH}_{3}$ and $\mathrm{CH}_{4}$ were $0.95,0.96$ and 0.93 , respectively.

Our results indicate that it is possible to measure $\mathrm{N}_{2} \mathrm{O}, \mathrm{NH}_{3}, \mathrm{CH}_{4}$ and $\mathrm{HCHO}$ during on-road operation. Moreover, the study shows the importance of the measurement of the emissions of these pollutants during real-world driving operation, as the emissions of the $\mathrm{PM}_{2.5}$ precursor $\mathrm{NH}_{3}$, and those of the pollutants and green-house gases $\mathrm{N}_{2} \mathrm{O}$ and $\mathrm{CH}_{4}$ can be high from some vehicle technologies. 
$\mathrm{NH}_{3}$ emissions were up to $49 \mathrm{mg} / \mathrm{km}$ for gasoline vehicles, up to $69 \mathrm{mg} / \mathrm{km}$ for the CNG-LCV and up to $17 \mathrm{mg} / \mathrm{km}$ for the DV1 (equipped with an SCR and without ASC). $\mathrm{N}_{2} \mathrm{O}$ and $\mathrm{CH}_{4}$ emissions accounted for up to $9.8 \mathrm{~g} \mathrm{CO}_{2}$ eqv/ $\mathrm{km}$ for the DV2 (equipped with DOC, LNT, SCR and possibly with ASC).

The obtained results indicate that the two Euro 6d-TEMP diesel vehicles studied were able to meet the Euro 6d-TEMP $\mathrm{NO}_{x}$ on-road emission requirement $(80 \mathrm{mg} / \mathrm{km} \times 2.1$ conformity factor $)$ in the RDE-compliant tests using different combinations of after-treatments. Nonetheless, the use of different after-treatment technologies led to the emissions of different non-regulated pollutants. Hence, the DV1 (equipped with an SCR and without an ASC) resulted in high emissions of $\mathrm{NH}_{3}$. The DV2 (equipped with DOC, LNT, SCR a possibly with ASC) showed high emissions of the GHGs $\mathrm{N}_{2} \mathrm{O}$ and $\mathrm{CH}_{4}$.

Supplementary Materials: The following are available online at http://www.mdpi.com/2073-4433/11/2/204/s1, Figure S1. Altitude profile (brown line) and speed profile (blue line) of (a) Route-1, (b) Route-2 and (c) Route-3; Figure S2. (a) $\mathrm{NH}_{3}$, (b) $\mathrm{CH}_{4}$ and (c) $\mathrm{N}_{2} \mathrm{O}$ emission profiles registered with the portable FTIR (orange line) and lab-grade FTIR (black line) during a WLTP test performed with DV1; Figure S3. $\mathrm{NH}_{3}, \mathrm{~N}_{2} \mathrm{O}, \mathrm{NO}, \mathrm{NO}_{2}, \mathrm{CO}, \mathrm{CH}_{4}$, and $\mathrm{HCHO}$ on-road emissions profiles registered during a DPF regeneration event of the DV1; Figure S4. (a) CO emission profile from the CNG-LCV measured using NDIR present in the PEMS (black line) and the portable FTIR (red line). (b) $\mathrm{CO}$ emission profile (red line) and $\mathrm{N}_{2} \mathrm{O}$ emission profile (blue line) measured using the portable FTIR.

Author Contributions: Conceptualization, R.S.-B. and M.P.; methodology, R.S.-B. and C.A.; software, M.P. and M.V.; validation, All; formal analysis, R.S.-B. and M.P.; investigation, R.S.-B. and M.P.; resources, All; data curation, R.S.-B. and M.P.; writing-original draft preparation, R.S.-B.; writing-review and editing, All; visualization, R.S.-B. and M.P.; supervision, R.S.-B.; project administration, R.S.-B. and C.A.; funding acquisition, All. All authors have read and agree to the published version of the manuscript.

Acknowledgments: The authors would like to acknowledge the support and collaboration of Cadario, M. Carriero, P. Le Lijour, M. Sculati, and M. Otura-Garcia.

Conflicts of Interest: The authors declare no conflict of interest.

Disclaimer: The opinions expressed in this manuscript are those of the authors and should not be considered to represent an official position of the European Commission.

\section{References}

1. European Environmental Agency. EEA Report No 12/2018 Air Quality in Europe-2018 Report; European Environmental Agency: Copenhagen, Denmark, 2018; ISBN 978-92-9213-989-6. ISSN 1977-8449. [CrossRef]

2. Kim, B.M.; Teffera, S.; Zeldin, M.D. Characterization of PM2.5 and PM10 in the South Coast Air Basin of Southern California: Part 1-Spatial Variations. J. Air Waste Manag. Assoc. 2000, 50, 2034-2044. [CrossRef]

3. Phan, N.-T.; Kim, K.-H.; Shon, Z.-H.; Jeon, E.-C.; Jung, K.; Kim, N.-J. Analysis of ammonia variation in the urban atmosphere. Atmos. Environ. 2013, 65, 177-185. [CrossRef]

4. Guan, B.; Zhan, R.; Lin, H.; Huang, Z. Review of state of the art technologies of selective catalytic reduction of NOx from diesel engine exhaust. Appl. Therm. Eng. 2014, 66, 395-414. [CrossRef]

5. Ko, J.; Myung, C.-L.; Park, S. Impacts of ambient temperature, DPF regeneration, and traffic congestion on NOx emissions from a Euro 6-compliant diesel vehicle equipped with an LNT under real-world driving conditions. Atmos. Environ. 2018, 200,1-14. [CrossRef]

6. Suarez-Bertoa, R.; Zardini, A.A.; Astorga, C. Ammonia exhaust emissions from spark ignition vehicles over the New European Driving Cycle. Atmos. Environ. 2014, 97, 43-53. [CrossRef]

7. Suarez-Bertoa, R.; Astorga, C. Isocyanic acid and ammonia in vehicle emissions. Transp. Res. Part D 2016, 49, 259-270. [CrossRef]

8. Wallington, T.J.; Wiesen, P. $\mathrm{N}_{2} \mathrm{O}$ emissions from global transportation. Atmos. Environ. 2014, 94, $258-263$. [CrossRef]

9. Ravishankara, A.R.; Daniel, J.S.; Portmann, R.W. Nitrous Oxide ( $\left.\mathrm{N}_{2} \mathrm{O}\right)$ : The Dominant Ozone-Depleting Substance Emitted in the 21st Century. Science 2009, 326, 123-125. [CrossRef] [PubMed]

10. Finlayson-Pitts, B.J.; Pitts, J.N. Chemistry of the Upper and Lower Atmosphere; Elsevier: New York, NY, USA, 1999.

11. Behera, S.N.; Sharma, M. Investigating the potential role of ammonia in ion chemistry of fine particulate matter formation for an urban environment. Sci. Total Environ. 2010, 408, 3569-3575. [CrossRef] [PubMed] 
12. Sillanpää, M.; Hillamo, R.; Saarikoski, S.; Frey, A.; Pennanen, A.; Makkonen, U.; Spolnik, Z.; Van Grieken, R.; Braniš, M.; Brunekreef, B.; et al. Chemical composition and mass closure of particulate matter at six urban sites in Europe. Atmos. Environ. 2006, 40, 212-223. [CrossRef]

13. Pinder, R.W.; Adams, P.J.; Pandis, S.N. Ammonia Emission Controls as a Cost-Effective Strategy for Reducing Atmospheric Particulate Matter in the Eastern United States. Environ. Sci. Technol. 2007, 41, 380-386. [CrossRef] [PubMed]

14. Paulot, F.; Jacob, D.J. Hidden Cost of U.S. Agricultural Exports: Particulate Matter from Ammonia Emissions. Environ. Sci. Technol. 2014, 48, 903-908. [CrossRef] [PubMed]

15. Shindell, D.T.; Faluvegi, G.; Koch, D.M.; Schmidt, G.A.; Unger, N.; Bauer, S.E. Improved Attribution of Climate Forcing to Emissions. Science 2009, 326, 716-718. [CrossRef] [PubMed]

16. IPCC. Intergovernmental Panel on Climate Change; Cambridge University Press: Cambridge, UK, 2013.

17. Sutton, M.A.; Erisman, J.W.; Dentener, F.; Möller, D. Ammonia in the environment: From ancient times to the present. Environ. Pollut. 2008, 156, 583-604. [CrossRef] [PubMed]

18. Bouwman, A.F.; Lee, D.S.; Asman Asman, W.A.H.; Dentener, F.J.; Van Der Hoek, K.W.; Olivier, J.G.J. A global high-resolution emission inventory for ammonia. Glob. Biogeochem. Cycles 1997, 11, 561-587. [CrossRef]

19. Erisman, J.W.; Grennfelt, P.; Sutton, M. The European perspective on nitrogen emission and deposition. Environ. Int. 2003, 29, 311-325. [CrossRef]

20. Kirkby, J.; Curtius, J.; Almeida, J.; Dunne, E.; Duplissy, J.; Ehrhart, S.; Franchin, A.; Gagne, S.; Ickes, L.; Kurten, A.; et al. Role of sulphuric acid, ammonia and galactic cosmic rays in atmospheric aerosol nucleation. Nature 2011, 476, 429-433. [CrossRef]

21. Fenn, M.; Bytnerowicz, A.; Schilling, S.; Vallano, D.; Zavaleta, E.; Weiss, S.; Morozumi, C.; Geiser, L.; Hanks, K. On-road emissions of ammonia: An underappreciated source of atmospheric nitrogen deposition. Sci. Total Environ. 2018, 625, 909-919. [CrossRef]

22. Sun, K.; Tao, L.; Miller, D.; Pan, D.; Golston, L.; Zondlo, M.; Griffin, R.; Wallace, H.; Leong, Y.; Yang, M.; et al. Vehicle Emissions as an Important Urban Ammonia Source in the United States and China. Environ. Sci. Technol. 2017, 51, 2472-2481. [CrossRef]

23. Osada, K.; Saito, S.; Tsurumaru, H.; Hoshi, J. Vehicular exhaust contributions to high $\mathrm{NH}_{3}$ and $\mathrm{PM}_{2.5}$ concentrations during winter in Tokyo, Japan. Atmos. Environ. 2019, 206, 218-224. [CrossRef]

24. Dabek-Zlotorzynska, E.; Celo, V.; Ding, L.; Herod, D.; Jeong, C.; Evans, G.; Hilker, N. Characteristics and sources of PM2.5 and reactive gases near roadways in two metropolitan areas in Canada. Atmos. Environ. 2019, 218, 116980. [CrossRef]

25. Elser, M.; El-Haddad, I.; Maasikmets, M.; Bozzetti, C.; Wolf, R.; Ciarelli, G.; Slowik, J.; Richter, R.; Teinemaa, E.; Hüglin, C.; et al. High contributions of vehicular emissions to ammonia in three European cities derived from mobile measurements. Atmos. Environ. 2018, 175, 210-220. [CrossRef]

26. U.S. 40 CFR § 86.1811-17—Exhaust Emission Standards for Light-Duty Vehicles, Light-Duty Trucks and Medium-Duty Passenger Vehicles. Available online: https:/www.govinfo.gov/content/pkg/CFR-2014-title40vol19/pdf/CFR-2014-title40-vol19-sec86-1811-17.pdf (accessed on 12 February 2020).

27. Bishop, G.A.; Stedman, D.H. Reactive Nitrogen Species Emission Trends in Three Light-/Medium-Duty United States Fleets. Environ. Sci. Technol. 2015, 49, 11234-11240. [CrossRef] [PubMed]

28. Link, M.F.; Kim, J.; Park, G.; Lee, T.; Park, T.; Babar, Z.B.; Sung, K.; Kim, P.; Kang, S.; Kim, J.S.; et al. Elevated production of NH4NO3 from the photochemical processing of vehicle exhaust: Implications for air quality in the Seoul Metropolitan Region. Atmos. Environ. 2017, 156, 95-101. [CrossRef]

29. Suarez-Bertoa, R.; Astorga, C. Unregulated emissions from light-duty hybrid electric vehicles. Atmos. Environ. 2016, 136, 134-143. [CrossRef]

30. Suarez-Bertoa, R.; Pavlovic, J.; Trentadue, G.; Otura-Garcia, M.; Tansini, A.; Ciuffo, B.; Astorga, C. Effect of low ambient temperature on emissions and electric range of plug-in hybrid electric vehicles. ACS Omega 2019, 4, 3159-3168. [CrossRef]

31. Suarez-Bertoa, R.; Mendoza-Villafuerte, P.; Riccobono, F.; Vojtisek, M.; Pechout, M.; Perujo, A.; Astorga, C. On-road measurement of $\mathrm{NH}_{3}$ emissions from gasoline and diesel passenger cars during real world driving conditions. Atmos. Environ. 2017, 166, 488-497. [CrossRef]

32. Suarez-Bertoa, R.; Astorga, C. Impact of cold temperature on Euro 6 passenger car emissions. Environ. Pollut. 2018, 234, 318-329. [CrossRef] 
33. Suarez-Bertoa, R.; Mendoza-Villafuerte, P.; Bonnel, P.; Lilova, V.; Hill, L.; Perujo, A.; Astorga, C. On-road measurement of $\mathrm{NH}_{3}$ and $\mathrm{N}_{2} \mathrm{O}$ emissions from a Euro $\mathrm{V}$ heavy-duty vehicle. Atmos. Environ. 2016, 139, 167-175. [CrossRef]

34. Mendoza-Villafuerte, P.; Suarez-Bertoa, R.; Giechaskiel, B.; Riccobono, F.; Bulgheroni, C.; Astorga, C.; Perujo, A. $\mathrm{NO}_{x}, \mathrm{NH}_{3}, \mathrm{~N}_{2} \mathrm{O}$ and $\mathrm{PN}$ real driving emissions from a Euro VI heavy-duty vehicle. Impact of regulatory on-road test conditions on emissions. Sci. Total Environ. 2017, 609, 546-555. [CrossRef]

35. Vojtíšek-Lom, M.; Beránek, V.; Klír, V.; Jindra, P.; Pechout, M.; Voříšek, T. On-road and laboratory emissions of $\mathrm{NO}, \mathrm{NO}_{2}, \mathrm{NH}_{3}, \mathrm{~N}_{2} \mathrm{O}$ and $\mathrm{CH}_{4}$ from late-model EU light utility vehicles: Comparison of diesel and CNG. Sci. Total Environ. 2018, 616-617, 774-784. [CrossRef] [PubMed]

36. European Commission. Commission regulation (EU) 2017/1151 of 1 June 2017 supplementing Regulation (EC) No 715/2007 of the European Parliament and of the Council on type-approval of motor vehicles with respect to emissions from light passenger and commercial vehicles (Euro 5 and Euro 6) and on access to vehicle repair and maintenance information, amending Directive 2007/46/EC of the European Parliament and of the Council, Commission Regulation (EC) No 692/2008 and Commission Regulation (EU) No 1230/2012 and repealing Commission Regulation (EC) No 692/2008. Off. J. Eur. Union 2017, 175, 1-643.

37. UNECE. Regultaion 83 Concerning the Adoption of Uniform Technical Prescriptions for Wheeled Vehicles, Equipment and Parts which can be Fitted and/or be Used on Wheeled Vehicles and the Conditions for Reciprocal Recognition of Approvals Granted on the Basis of these Prescriptions (2013). Available online: https://www.unece.org/fileadmin/DAM/trans/main/wp29/wp29regs/R083r5e.pdf (accessed on 13 February 2020).

38. Clairotte, M.; Valverde, V.; Bonnel, P.; Giechaskiel, B.; Carriero, M.; Otura, M.; Fontaras, G.; Pavlovic, J.; Martini, G.; Krasenbrink, A.; et al. Joint Research Centre 2017 Light-Duty Vehicles Emissions Testing-Contribution to the EU Market Surveillance: Testing Protocols and Vehicle Emissions Performance; EUR 29302 EN; Publications Office of the European Union: Luxembourg, 2018; ISBN 978-92-79-90600-8. [CrossRef]

39. Valverde, V.; Clairotte, M.; Bonnel, P.; Giechaskiel, B.; Carriero, M.; Otura, M.; Gruening, C.; Fontaras, G.; Pavlovic, J.; Martini, G.; et al. Joint Research Centre 2018 Light-Duty Vehicles Emissions Testing—Contribution to the EU Market Surveillance: Testing Protocols and Vehicle Emissions Performance EUR29897 EN; Publications Office of the European Union: Luxembourg, 2019; ISBN 978-92-76-12333-0. [CrossRef]

40. European Commission. Commission Regulation (EU) 2018/1832 of 5 November 2018 amending Directive 2007/46/EC of the European Parliament and of the Council, Commission Regulation (EC) No 692/2008 and Commission Regulation (EU) 2017/1151 for the purpose of improving the emission type approval tests and procedures for light passenger and commercial vehicles, including those for in-service conformity and real-driving emissions and introducing devices for monitoring the consumption of fuel and electric energy. Off. J. Eur. Union 2018, 301, 1-314.

41. Suarez-Bertoa, R.; Lähde, T.; Pavlovic, J.; Valverde, V.; Clairotte, M.; Giechaskiel, B. Laboratory and On-Road Evaluation of a GPF-Equipped Gasoline Vehicle. Catalysts 2019, 9, 678. [CrossRef]

42. Graham, L.; Belisle, S.; Rieger, P. Nitrous oxide emissions from light duty vehicles. Atmos. Environ. 2009, 43, 2031-2044. [CrossRef]

43. Schuetzle, D.; Siegl, W.O.; Jensen, T.E.; Dearth, M.A.; Kaiser, E.W.; Gorse, R.; Kreucher, W.; Kulik, E. The relationship between gasoline composition and vehicle hydrocarbon emissions: A review of current studies and future research needs. Environ. Health Perspect. 1994, 102, 3-12. [CrossRef]

44. Rodriguez, F.; Dornoff, J. Beyond NOx: Emissions of Unregulated Pollutants from a Modern Gasoline Car; The International Council on Clean Transportation (ICCT): Berlin, Germany, 2019.

45. Suarez-Bertoa, R.; Zardini, A.A.; Lilova Meyer, D.; Nakatani, S.; Hibel, F.; Ewers, J.; Clairotte, M.; Hill, L.A.; Astorga, C. Intercomparison of real-time tailpipe ammonia measurements from vehicles tested over the new world-harmonized light-duty vehicle test cycle (WLTC). Environ. Sci. Pollut. Res. 2015, 22, 7450-7460. [CrossRef]

46. Suarez-Bertoa, R.; Clairotte, M.; Arlitt, B.; Nakatani, S.; Hill, L.; Winkler, K.; Kaarsberg, C.; Knauf, T.; Zijlmans, R.; Boertien, H.; et al. Intercomparison of ethanol, formaldehyde and acetaldehyde measurements from a flex-fuel vehicle exhaust during the WLTC. Fuel 2017, 203, 330-340. [CrossRef] 
47. Simonen, P.; Kalliokoski, J.; Karjalainen, P.; Rönkkö, T.; Timonen, H.; Saarikoski, S.; Aurela, M.; Bloss, M.; Triantafyllopoulos, G.; Kontses, A.; et al. Characterization of laboratory and real driving emissions of individual Euro 6 light-duty vehicles-Fresh particles and secondary aerosol formation. Environ. Pollut. 2019, 255, 113175. [CrossRef]

48. Wang, X.; Ge, Y.; Gong, H.; Yang, Z.; Tan, J.; Hao, L.; Su, S. Ammonia emissions from China-6 compliant gasoline vehicles tested over the WLTC. Atmos. Environ. 2019, 199, 136-142. [CrossRef]

49. Vieira-Filho, M.S.; Ito, D.T.; Pedrotti, J.J.; Coelho LH, G.; Fornaro, A. Gas-phase ammonia and water-soluble ions in particulate matter analysis in an urban vehicular tunnel. Environ. Sci. Pollut. Res. 2016, 23, 19876-19886. [CrossRef] [PubMed]

50. Whittington, B.I.; Jiang, C.J.; Trimm, D.L. Vehicle exhaust catalysis: I. The relative importance of catalytic oxidation, steam reforming and water-gas shift reactions. Catal. Today 1995, 26, 41-45. [CrossRef]

51. Livingston, C.; Rieger, P.; Winer, A. Ammonia emissions from a representative in-use fleet of light and medium-duty vehicles in the California South Coast Air Basin. Atmos. Environ. 2009, 43, 3326-3333. [CrossRef]

52. Suarez-Bertoa, R.; Valverde-Morales, V.; Clairotte, M.; Pavlovic, J.; Giechaskiel, B.; Franco, V.; Kregar, Z.; Astorga-LLorens, C. On-road emissions of passenger cars beyond the boundary conditions of the real-driving emissions test. Environ. Res. 2019, 176, 108572. [CrossRef]

53. Demuynck, J.; Favre, C.; Bosteels, D.; Hamje, H.; Andersson, J. Real-World Emissions Measurements of a Gasoline Direct Injection Vehicle without and with a Gasoline Particulate Filter; SAE: Warrendale, PA, USA, 2017 ; No. 2017-01-0985. [CrossRef]

54. Kelly, N.A.; Groblicki, P.J. Real-world emissions from a modern production vehicle driven in Los Angeles. J. Air Waste Manag. Assoc. 1993, 43, 1351-1357. [CrossRef]

55. Giechaskiel, B.; Suarez-Bertoa, R.; Lähde, T.; Clairotte, M.; Carriero, M.; Bonnel, P.; Maggiore, M. Emissions of a Euro $6 \mathrm{~b}$ diesel passenger car retrofitted with a solid ammonia reduction system. Environ. Res. 2018, 166, 298-309. [CrossRef] [PubMed]

56. Giechaskiel, B.; Suarez-Bertoa, R.; Lahde, T.; Clairotte, M.; Carriero, M.; Bonnel, P.; Maggiore, M. Evaluation of NOx emissions of a retrofitted Euro 5 passenger car for the Horizon prize "Engine retrofit". Atmosphere 2019, 10, 4. [CrossRef]

57. Valverde, V.; Mora, B.A.; Clairotte, M.; Pavlovic, J.; Suarez-Bertoa, R.; Giechaskiel, B.; Astorga-LLorens, C.; Fontaras, G. Emission factors derived from 13 Euro $6 \mathrm{~b}$ light-duty vehicles based on laboratory and on-road measurements. Atmosphere 2019, 10, 243. [CrossRef]

58. Suarez-Bertoa, R.; Kousoulidou, M.; Clairotte, M.; Giechaskiel, B.; Nuottimäki, J.; Sarjovaara, T.; Lonza, L. Impact of HVO blends on modern diesel passenger cars emissions during real world operation. Fuel 2019, 235, 1427-1435. [CrossRef]

59. Rašić, D.; Rodman Oprešnik, S.; Seljak, T.; Vihar, R.; Baškovič, U.; Wechtersbach, T.; Katrašnik, T. RDE-based assessment of a factory bi-fuel CNG/gasoline light-duty vehicle. Atmos. Environ. 2017, 167, 523-541. [CrossRef]

60. Jahirul, M.I.; Masjuki, H.H.; Saidur, R.; Kalam, M.A.; Jayed, M.H.; Wazed, M.A. Comparative engine performance and emission analysis of CNG and gasoline in a retrofitted car engine. Appl. Therm. Eng. 2010, 30, 2219-2226. [CrossRef]

(C) 2020 by the authors. Licensee MDPI, Basel, Switzerland. This article is an open access article distributed under the terms and conditions of the Creative Commons Attribution (CC BY) license (http://creativecommons.org/licenses/by/4.0/). 